\title{
John Michael Naish
}

The last sentence of this Obituary (BMJ 2009;339:b5168, doi:10.

1136/bmj.b5168) should have read that John Michael Naish

Cite this as: BMJ 2014;349:g7263

was survived by Barbara, his six children, and 12 grandchildren.

๑ BMJ Publishing Group Ltd 2014 